\title{
Tactical Dilatory Practice in Litigation: Evidence from EC Merger Proceedings
}

\author{
Peter L Ormosi \\ Norwich Business School, University of East Anglia, \\ UK
}

\section{CCP Working Paper 11-12}

\begin{abstract}
The economic analysis of delay in legal procedures has received considerable attention in the past. Most of these works focus on the determinants of delay in litigation but very little analysis has been dedicated to examining tactical delay caused by the parties to the litigation. This paper offers an empirical example to fill some of this gap by analysing strategic delay in pre-trial administrative litigation. The paper shows that in European merger litigation parties may decide to tactically challenge discovery attempts, which causes a delay that is strategically used to gain more time to settle the case and to avoid a lengthy in-depth investigation, similar to the prediction of Miceli's (1999) theoretical model. This type of delay can be beneficial to merging parties and to society as well.

August 2011
\end{abstract}

JEL Codes: K21, K41

Keywords: Litigation costs, tactical delay, antitrust law, mergers.

Acknowledgements: I would like to thank Steve Davies and Morten Hviid for the useful comments on earlier versions of this paper. All remaining errors are mine. The usual disclaimer applies. The support of the Economic and Social Research Council, and the Centre for Competition Policy is also gratefully acknowledged. 
Contact Details:

Peter Ormosi Norwich Business School and ESRC Centre for Competition Policy, University of East Anglia, NR4 7TJ, Norwich, United Kingdom, email: p.ormosi@uea.ac.uk 


\title{
Tactical Dilatory Practice in Litigation: Evidence from EC Merger Proceedings
}

\author{
Peter L. Ormosi* \\ Norwich Business School, University of East Anglia, UK
}

August 11, 2011

*Norwich Business School and ESRC Centre for Competition Policy, University of East Anglia, NR4 7TJ, Norwich, United Kingdom, email: p.ormosi@uea.ac.uk. I would like to thank Steve Davies and Morten Hviid for the useful comments on earlier versions of this paper. All remaining errors are mine. The usual disclaimer applies. The support of the Economic and Social Research Council, and the Centre for Competition Policy is also gratefully acknowledged. 


\begin{abstract}
The economic analysis of delay in legal procedures has received considerable attention in the past. Most of these works focus on the determinants of delay in litigation but very little analysis has been dedicated to examining tactical delay caused by the parties to the litigation. This paper offers an empirical example to fill some of this gap by analysing strategic delay in pre-trial administrative litigation. The paper shows that in European merger litigation parties may decide to tactically challenge discovery attempts, which causes a delay that is strategically used to gain more time to settle the case and to avoid a lengthy in-depth investigation, similar to the prediction of Miceli's (1999) theoretical model. This type of delay can be beneficial to merging parties and to society as well.
\end{abstract}

\title{
JEL Classification codes: K21, K41
}

Keywords: litigation costs, tactical delay, antitrust law, mergers 


\section{Introduction}

A delaying tactic or strategic delay is a litigation strategy applied by typically one of the parties to intentionally delay a legal procedure. Examples of delaying tactics include jurisdictional challenges, discovery challenges, challenging the arbitrator, or requesting new expert evidence or a site visit. Because delaying tactics lengthen the litigation and lead to higher litigation costs they are generally perceived negatively by the public and by the legal profession as well. ${ }^{1}$

Although finding the main determinants of delay in litigation has been subject to much academic work, ${ }^{2}$ relatively little attention has been dedicated to the analysis of tactical dilatory practices that are induced by one of the parties to the litigation. These practices are typically regarded to only serve unethical reasons to wear down the other party or to lower the settlement offer. ${ }^{3}$ Miceli (1999) challenges this perception and shows that delay initiated by the defendants may be beneficial if it allows those cases to settle that the defendant otherwise would have taken to trial. Although Miceli's findings to date have been but a theoretical possibility, the main contribution of this paper is the provision of an example to support these findings empirically in a situation where strategic delay has a socially desirable effect.

Lawyers in most jurisdictions are not allowed to apply delaying tactics abusively. ${ }^{4}$ Hazard and Hodes (2001) argue that this does not per se bar strategic

\footnotetext{
${ }^{1}$ For a legal perspective on tactical delay see Fré (2005).

${ }^{2}$ For a general analysis of the determinants of delay see Kessler (1996), Fournier and Zuehlke (1996). Other works focused more on analysing the drivers of delay on the 'demand side of the justice market' (as coined by Vita (2010)), especially for soliciting delay when lawyers are renumerated by the duration of their engagement, see: Dewatripont and Tirole (1999), Djankov, La Porta, López de Silanes, and Shleifer (2003).

${ }^{3}$ Through a detailed and insightful discussion of the Pennzoil Texaco case Mnookin and Wilson (1989) provide a good example of how the prospect of delay lowered settlement significantly.

${ }^{4}$ Rule 3.2 of the ABA Model Rules of Professional Conduct reads: "A lawyer shall make reasonable efforts to expedite litigation consistent with the interests of the client." Without explicitly referring to dilatory practices, Paragraph 4.2 of the code of conduct for European lawyers states that "a lawyer must always have due regard for the fair conduct of proceedings."
} 
behaviour (including tactical delay) in litigation but only prohibits unreasonable obstacles to expediting litigation. To delineate normal strategic conduct from unethical tactical behaviour typically a competent lawyer test is used ${ }^{5}$ and an exemplificative guidance is provided on what would constitute improper delay. For example realising financial or other benefits from otherwise improper delay in litigation is not considered a legitimate interest of the client, similarly it is not appropriate for a lawyer to routinely fail to expedite litigation solely for the convenience of the advocates, or if a failure to expedite is done for the purpose of frustrating an opposing party's attempt to obtain a rightful redress or repose. ${ }^{6}$ Although not mentioned explicitly as a type of strategic delay, given the difference in cost of litigation depending on whether the settlement is reached pre-trial, this paper relies on the premise that the behaviour identified by Miceli (i.e. where delay is caused in order to avoid trial) would also pass the competent lawyer test.

The empirical example presented in this paper is taken from EC merger control. Although it is not civil litigation, it has the advantage of the procedures being well documented. This enables the distinction between delay induced by the parties to the case and other types of delay, and it also allows the identification of the exact start date and the duration of delay. There are also numerous analogies between administrative and civil litigation. In administrative proceedings parties are often given the chance to settle the case in order to avoid either a more in-depth administrative investigation, or a court trial. These procedures therefore can be thought of as a pre-trial phase of litigation.

The paper provides evidence that in the EC merger control framework merging parties tactically delay the proceedings in order to gain some time to settle the case and avoid further delay in the form of an in-depth and lengthy investigation. The socially beneficial effect that was identified by Miceli how-

\footnotetext{
${ }^{5}$ For example Rule 3.2 of the ABA Model Rules says: "The question is whether a competent lawyer acting in good faith would regard the course of action as having some substantial purpose other than delay."

${ }^{6}$ Hazard and Hodes (2001) suggest that, when the legitimacy of expediting litigation and the client's interest in a delay contradicts, the latter should always subordinate.
} 
ever only characterises delays that happen early in the procedure. Delays in the second phase of the proceedings do not seem to have the same socially desirable effect. A possible explanation to this would be that whereas the first type of delay is motivated by the higher costs of delay, mergers in the second group are those with lower costs of delay.

The paper first gives a brief insight into the EC merger control framework, which is followed by a discussion of the empirical model. Once the relevant variables are introduced, the results are presented and discussed.

\section{The European merger control framework}

Merger control in the EC is regulated by the ECMR. ${ }^{7}$ The primary focus of European merger control regime is on detecting mergers that in their net effect reduce the level of competition in a market. These mergers only receive regulatory approval if the parties to the merger offer to modify the merger in a way that eliminates the negative effects on competition (merger remedy). Merging parties can therefore settle the case by making a suitable remedy offer.

Phase I and phase II investigations are the commonly used shorthand terms for the two procedural stages of the Commission's merger review procedures. Phase I procedures refer to the initial examination of the notified merger cases. Following the reception of the notification, the Commission has a period of 25 working days before a decision on the merger has to be made. This deadline can be further extended to 35 days if the parties offer commitments to remedy the anticompetitive effects of the merger. Phase I proceedings can be thought of as an analogy to the pre-trial phase of litigation. The advantage of these proceedings is the ability to settle a case without unnecessarily burdening scarce public resources or increasing the costs of all parties to the litigation. ${ }^{8}$

\footnotetext{
${ }^{7}$ Council Regulation (EC) No 139/2004 of 20 January 2004 on the Control of Concentrations Between Undertakings (OJ L 24, 29.01.2004, p. 1-22).

${ }^{8}$ The judicial review of European Commission merger decisions has been cited as making the approval of the merger practically meaningless from a commercial point of view. See Heim (2003).
} 
If the case is not settled in phase I, the Commission initiates a phase II investigation, where the Commission has 90 additional working days to reach a decision (if remedies are offered before day 55 of the second phase investigation), which may be extended by 15 working days if remedies are offered after day 55, and by a further 20 days at the request of the merging parties or as an initiative from the Commission subject to the approval of the merging parties. Phase II can also be thought of as an analogy to a pre-trial case, although with significantly increased litigation costs. As merger prohibitions are typically challenged by the merging parties, prohibition practically signifies the start of court litigation.

Article 10 (4) of the ECMR declares that the Commission may exceptionally suspend these proceedings owing to circumstances for which one of the merging parties is responsible. ${ }^{9}$ As the relevant EC legislation does not establish a time frame for these suspensions, this can substantially delay the proceedings. As suspension is a result of merging parties' failure to provide information to the Commission, merging parties and their legal advisors can tactically withhold some information from the Commission to delay the procedure. The following discussion examines some of the motivators of this type of tactical delay.

\subsection{The analysed cases}

11 years of EC merger decisions (1999-2009) with 214 cases are included the empirical analysis. ${ }^{10}$ As the paper looks at tactical delay motivated by the willingness to gain more time for an adequate remedial offer, a common denominator of the sample cases was that they all necessitated intervention from the Commission's part (i.e. parties had to make a settlement offer). The data was collected from two sources: (a) the Commission's case reports, and (b) the Hearing Officer's reports. The sampling process used for this research was

\footnotetext{
${ }^{9}$ To request information by decision pursuant to Article 11 or to order an inspection by decision pursuant to Article 13.

${ }^{10}$ The use of earlier cases was rejected as the information available from Commission case reports becomes very fuzzy for cases before 1999 .
} 
- in a sense - purposive sampling as it collected all of those European Commission cases within the analysed timeframe which involved intervention from the Commission's part. ${ }^{11}$ The fact that the sample contains more than 90 percent of all intervention cases for the analysed period should also increase the robustness of the empirical findings of this paper.

\section{$2.2 \quad$ Summary statistics}

Table 1 contains summary statistics for the length of procedures in the analysed period (1999-2009). It reveals that despite the strict deadlines, there is a large dispersion in the length of investigations, and the mean length of investigation is also significantly longer than the regulatory set maximum.

Table 1: The Length of EC Merger Procedures (1999-2009)

\begin{tabular}{llllll}
\hline Description & N & mean & std.dev. & min & max \\
\hline \hline With suspension & & & & & \\
$\begin{array}{l}\text { Number of working days between } \\
\text { notification and final decision }\end{array}$ & 214 & 65.85 & 44.87 & 23 & 249 \\
$\begin{array}{l}\text { phase I } \\
\text { phase II }\end{array}$ & 149 & 39.08 & 14.78 & 23 & 147 \\
\hline $\begin{array}{l}\text { Without suspension } \\
\text { Number of working days between }\end{array}$ & 214 & 59.76 & 39.64 & 18 & 155 \\
$\begin{array}{l}\text { notification and final decision } \\
\text { phase I }\end{array}$ & 149 & 34.28 & 3.74 & 18 & 43 \\
phase II & 65 & 118.18 & 14.81 & 80 & 155
\end{tabular}

Despite a well-defined procedural framework, the possibility of suspension creates large dispersion in the length of proceedings. The lower section of Table 1 shows that - having taken away the length of suspension - we can observe a drop in the mean and particularly in the variance and maximum values of the length of investigations, especially in phase I procedures. ${ }^{12}$

\footnotetext{
${ }^{11}$ The only constraint affecting the collected sample was that only English and French texts were included. From the 232 cases between 1999 and 2009, twelve were in German, three in Italian, and three in Spanish, leaving 214 cases to be analysed.

${ }^{12}$ Apart from the cases where suspension was explicitly mentioned in the merger decision,
} 
In the analysed cases there were 40 suspensions reported (29 phase I and 11 phase II). For the remainder of the cases it was assumed that the investigation was not suspended. Table 2 summarises the number of suspension cases in phase I and phase II procedures, broken down into cases under the old and the new ECMR.

Table 2: Number of Cases with Suspension (1999-2009)

\begin{tabular}{llll}
\hline & Phase I & Phase II & Total \\
\hline Old ECMR & 23 & 3 & 26 \\
New ECMR & 6 & 8 & 14 \\
\hline Total & 29 & 11 & 40
\end{tabular}

Although the ECMR reserves the suspension of investigation to exceptional situations, suspended procedures amount to nearly a fifth of all intervention cases. Under the old ECMR (pre-2004) there were more phase I than phase II suspensions, but this relationship reversed under the current ECMR.

Table 3: The length of procedural suspensions (1999-2009)

\begin{tabular}{llllll}
\hline Description & $\mathbf{N}$ & mean & std.dev. & min & max \\
\hline $\begin{array}{l}\text { Length of suspension in } \\
\text { working days }\end{array}$ & 40 & 33.28 & 24.52 & 3 & 116 \\
phase I & & & & & \\
phase II & 29 & 34.89 & 23.58 & 3 & 116 \\
& 11 & 31.82 & 28.49 & 5 & 94
\end{tabular}

Table 3 summarises the length of suspension in those cases where suspension was reported, and shows that the length of suspensions is higher in phase I cases both in absolute and relative terms. ${ }^{13}$

there were another 73 cases, where the length of the procedure exceeded (typically by a couple of working days) the regulatory limit but the source of delay is not reported in the text of the decision. In 16 of these cases the case was referred to the Commission from a Member State authority, which could also have caused some delay.

${ }^{13}$ Phase I proceedings are much shorter than phase II investigations. 


\section{$3 \quad$ Model for testing}

Because of the vast difference in litigation costs,${ }^{14}$ intuition would dictate that tactical delay may be motivated by different reasons in the initial assessment period than during a formal investigation or trial. Firms or their legal advisors may tactically choose not to comply with discovery requests in a pre-trial situation. For example, parties may fail to make a timely settlement offer in which case an investigation or a trial would have to be initiated, which would lead to a lengthy delay for parties. If, however, the procedure is suspended, then parties gain some more time to be able to come up with the right settlement. ${ }^{15}$ This type of behaviour can be socially beneficial as they reduce the risks associated with a longer delay in merger integration, and they also contribute to saving the scarce resources of competition authorities. If however the delaying strategy does not contribute to avoiding trial or further delay, then it is hard to see any other social benefits that would justify their use.

In the following model of merger procedures the merging parties decide whether to settle the case (offer a remedy) throughout the procedure, and also decide whether to delay the case by withholding information from the Commission. If a satisfactory remedy is offered early in phase I then the merger is approved in phase I and no further investigation is needed. The probability of phase II is therefore some function of early remedy-offers. If there is no early

\footnotetext{
${ }^{14}$ Looking at Australia Williams and Williams (1994) provide some empirical evidence that the main determinant of the cost of litigation is whether it goes to a trial stage.

${ }^{15}$ For example in the $G E / A G F A$ (Case No COMP/M.3136) case the investigation started on 14 May 2003, following a referral from several Member States, but was suspended 2 days later as the parties failed to provide the requested information to the Commission. After the parties submitted the requested information, the procedure restarted on 11 June 2003. The parties then submitted a proposal for remedies on 2 July. At roughly the same time the Commission requested further information. As this was not supplied in due time, the investigation was suspended again on 7 July. It took over 4 months - that is almost the length of a phase II investigation - before the requested documentation (together with a revised set of commitments) was submitted to the Commission and the case was restarted on 18 November 2003. As the second set of commitments was sufficient to remedy the anticompetitive effects of the merger, the Commission approved the merger on 5 December 2003 without referring the case to a second phase investigation. Similar thing happened for example in the Vodafone / Mannesmann merger (Case No COMP/M.1795 - Vodafone Airtouch / Mannesmann).
} 
remedy-offer, then - to gain some time - the parties may cause the suspension of the case, to find an adequate remedy. For this reason the suspension of the procedure is also expected to have an effect on the probability of phase II. From this information, a simple model of the propensity of phase II investigations would look as follows:

$$
\text { phaseII }=\alpha_{1}+\gamma_{11} \text { rem }+\gamma_{12} \text { suspp } 1+\gamma_{13}(\text { rem } \times \text { suspp } 1)+\mathbf{X}_{1} \beta_{1}+u_{1}
$$

Similarly for the second hypothesis, the propensity of prohibition could be expressed as:

$$
\text { prohib }=\alpha_{2}+\gamma_{21} \text { rem }+\gamma_{22} \text { suspp } 2+\gamma_{23}(\text { rem } \times \text { suspp } 2)+\mathbf{X}_{2} \beta_{2}+u_{2}
$$

Where the rem denotes whether a satisfying remedy had been offered in a timely manner, suspp 1 and suspp 2 denote if an investigation was suspended in phase I or in phase II respectively, $\mathbf{X}$ is a vector of other independent case-, and merger-specific characteristics, and $u_{1}$ and $u_{2}$ are two error terms, where phaseII and prohib denote whether a phase II procedure was started and whether the merger was prohibited by the Commission respectively.

One of the key questions is: what happens if a settlement is not offered in a timely fashion? Does the proceeding go into the second phase or can the parties still settle the case in phase I, and does the suspension (the delay) have any role to play in this? Similarly for the phase II suspension: what happens if remedies are not offered early enough and how suspension would affect the chances of early settlement in this case? The relevant coefficients in this respect are $\gamma_{12}$ and $\gamma_{22}$, which denote the partial effect of the suspension of the procedure on the probability of a phase II investigations and on the probability of prohibition, when an early remedy had not been offered. To test for Miceli's proposition, one would need to show that suspensions help to avoid phase II investigations or prohibition in cases where sufficient settlement offers had not been made early in the procedure, therefore $\gamma_{12}<0$, and/or 
$\gamma_{22}$.

Estimation of Equations (1) and (2) as probit models only provide consistent estimates if none of the regressors are jointly determined with the dependent variables. In the analysed case there may be a reason to believe that the suspension of the proceedings (suspp1 and suspp2) may correlate with variables omitted from and/or included in Equations (1) and (2), particularly with the timing of the remedy-offer, as parties would only need to strategically initiate the suspension of the procedure if they had failed to offer an adequate remedy earlier. The endogeneity of either of these variables would lead to bias in the coefficients of Equations (1) and (2), and the direction of the bias would be theoretically indeterminable because it depends not only on the correlation among the covariates but also on the nature of the omitted variable(s).

To detect endogeneity, the probability of phase II and the probability of suspension were estimated simultaneously using a recursive bivariate probit model. The simultaneous system of equations is given by: ${ }^{16}$

$$
\begin{aligned}
\text { phaseII }^{*} & =\alpha_{1}+\gamma_{11} \text { rem }+\gamma_{12} \text { suspp } 1+\gamma_{13}(\text { rem } \times \text { suspp } 1)+\mathbf{X}_{1} \beta_{1}+u(3) \\
{\text { suspp } 1^{*}}^{*} & \alpha_{2}+\gamma_{21} \text { rem }+\mathbf{X}_{2} \beta_{2}+u_{2}
\end{aligned}
$$

Where the dependent variables are defined as:

$$
\begin{aligned}
& \text { phaseII, suspp } 1=1 \text { if } \text { phaseII } I^{*}, \operatorname{suspp} 1^{*}>0 \\
& \text { phaseII, suspp } 1=0 \text { otherwise }
\end{aligned}
$$

For the system of Equations 3 and (4), $\left(u_{1}, u_{2}\right)$ is independent of $\mathbf{X}$ and assuming that $u_{1}$ and $u_{2}$ are jointly and normally distributed with mean zero and variance one, the correlation between them is denoted as $\rho=\operatorname{corr}\left(u_{1}, u_{2}\right)$. If $\rho$ is significantly different from zero, then the probit estimation of Equation

\footnotetext{
${ }^{16}$ As the models in Equations (1) and (2) are analytically very similar, hereby only the model for the probability of phase II procedures is explained, the model for the probability of prohibition can be derived analogously.
} 
3 is inconsistent for $\alpha_{1}, \gamma_{1 n}$ and $\beta_{1}$.

The estimation is done according to the following steps. Firstly Equations (3) and (4) are estimated simultaneously using a recursive bivariate probit model. To test for the endogeneity of the suspension of phase I procedures in the model, $\rho$ is calculated. If the hypothesis of $\rho=0$ is rejected then the recursive bivariate model's estimates are preferred, otherwise the single equation probit estimations are used.

\section{Introducing the variables}

Before looking at the results, the variables used for the estimation are briefly introduced. Unless otherwise stated, this information was collected from the Commission's published case reports. The summary statistics are provided in the Appendix.

\subsection{Dependent variables}

phaseII is a binary indicator, which takes on the value one for cases with a second phase investigation. suspp 1 and suspp 2 are the binary variables for phase I and phase II suspension respectively. It is important to emphasise that suspp $1=1$ means that suspension happened in the phase I stage and not necessarily in a phase I merger decision (i.e. in a phase II merger case, suspension may have happened before it was referred to phase II). Similarly, suspp $2=1$ denotes cases that were suspended in the second procedural phase (i.e. after the decision initiating proceedings under Article 6(1)(c) of the ECMR)

\subsection{Independent variables}

Firstly, both the timing of a remedy offer and the failure to disclose information to the Commission may depend strongly on how costly delay is for the merging firms. ${ }^{17}$ To find a measure of the cost of delay, the publicly signalled

\footnotetext{
${ }^{17}$ Choparda, Cortadeb, and Langlais (2010) emphasise the importance of looking at individual costs of delay as a main determinant of reaching settlement. Fenn and Rickman
} 
saving expectations of the merging parties (val) were used as a proxy. The reason for this choice is as follows. Mergers often communicate their synergy expectations to their shareholders pre-merger. Although it has been shown that some of these saving expectations fall short, pre-merger they increase the shareholder valuation of the merger, therefore higher saving expectations would imply higher cost of delay. This paper assumes that the communicated saving expectations are genuine expectations, therefore more of these expectations should mean more urgent mergers. Three major sources were used for collecting information on saving expectations: merging parties' annual reports; company press releases; and business-and-law search engines such as Lexis-Nexis. Google news archives were used to double-check the information acquired through the first two steps, or if the annual reports were not detailed enough or simply because there were no annual reports available. To ensure the validity of the data, it was only used if there were at least three different sources reporting the same synergy expectation, roughly at the same time. To acquire the val variable, the present value of the deflated annual cost savings was first calculated. As larger mergers are more likely to realise larger cost savings, the calculated present value of savings was divided by the size of the transaction $(p a)$. The data was deflated using quarterly indices (for the quarter of the merger notification). ${ }^{18}$

The size of the merger is also included in the model. Information on the value of the transaction was collected $(p a)$ to analyse the effect of merger size on the probability of successful remedy-offers. As data on the size of the transaction is not included in the EC case reports, it was acquired from merging parties' annual reports, and business press services (business newspapers, industry magazines, business-and-law search engines such as Lexis-Nexis). ${ }^{19}$

Probably the most important determinant of the probability of phase II proceedings is the timing of the remedy-offer. Information on the timing of remedy-offers was published in the Commission's case report, but it is not

(1999) showed that parties' with lower litigation costs are more likely to delay settlement.

${ }^{18}$ The UK Retail Price Index (RPI) was used (published on www.statistics.gov.uk).

${ }^{19}$ The data was deflated using quarterly indices (for the quarter of the merger notification) from the UK Retail Price Index (RPI) were used (published on www.statistics.gov.uk). 
reported in every decision, which resulted in 28 missing observations. From the available data there is no reason to think that these are not randomly missing. Remedies offered early in the procedure are expected to decrease the likelihood of a second phase investigation and that of prohibition. To facilitate the interpretation of the effect of suspension, information on the timing of remedy-offers was compressed into a set of dummy variables. Four different models were estimated both for Equations (1) and (2), depending on how the remedy-offer dummy was constructed. These were: remedy offered by day 20 (rem20), day 25 (rem25), day 30 (rem30) and day 35 (rem35) for Equation (1), and remedy offered by day 40 (rem40), day 60 (rem60), day 80 (rem80), and day 100 (rem100) for Equation (2). The advantage of using these dummies is that this way the suspension dummy gives us the effect of suspension where a remedy was not offered by day 20, 25, 30 and so on.

Another possible determinant of the analysed probabilities is the complexity of the given merger as more complex mergers are expected to be more likely to lead to phase II investigations, and/or prohibition. Three dimensions of complexity were included in the model, horizontal, vertical, and coordinated effect. To control for horizontal effects, the number of proportion of horizontal overlaps with competition concerns to the total number of horizontal overlaps (ovlperc) was used. Although this is a simple measure, it has the benefit of being available for all cases. ${ }^{20}$ Data for more sophisticated measures, such as overlaps, or entry characteristics are more likely to be only available for phase II than for phase I reports. Vertical effects (vert), and coordinated effects (coor) were included in the models using a simple binary variable.

The experience of the merging parties with regards the Commission's practice is also expected to play a role in the analysis. As firms become more familiar with the assessment of mergers, they become better suited at finding the right settlement offer as quick as possible. This was controlled for by using the case number (cno), which is the four-digit part of the Commission's case numbers. Cases are numbered in a chronological order following their notification to the Commission. A case with a higher number can be thought of as

\footnotetext{
${ }^{20}$ This is similar to the approach used by Garrod and Lyons (2011)
} 
one where the merging parties and/or the Commission have more experience.

\section{Estimation results and discussion}

The main results below are reported separately for phase I and II.

\subsection{Suspension in phase I}

The recursive bivariate probit estimates are reported in Table 7 for four different models, depending on how the remedy offer dummy was constructed (rem20, rem 25, rem30, rem35). To demonstrate the robustness of these estimates and test results, two models, using only the key dependent variables are also reported. The results of a Wald test, testing whether the correlation coefficient $\rho$ between the error terms equals zero, are also reported. These figures show that we cannot reject $\rho=0$ for any of the models, which is evidence that the single equation probit models provide consistent estimates.

Table 4: Probability of phase II - single equation probit estimates

\begin{tabular}{cc|c|c|c} 
& Model 1 & Model 2 & Model 3 & Model 4 \\
& rem20 & rem25 & rem30 & rem35 \\
\hline \hline suspp1 & -0.369 & $-0.856^{*}$ & $-1.523^{* * *}$ & $-2.696^{* * *}$ \\
& $(0.446)$ & $(0.460)$ & $(0.392)$ & $(0.440)$ \\
rem & $-1.367^{* * *}$ & $-2.047^{* * *}$ & $-2.777^{* * *}$ & $-4.271^{* * *}$ \\
& $(0.318)$ & $(0.314)$ & $(0.352)$ & $(0.400)$
\end{tabular}

The single equation probit estimates in Table $5^{21}$ reveal an important pattern. ${ }^{22}$ It clearly stands out that the later the remedy is offered, the stronger the impact of a suspension becomes on avoiding phase II investigations. This is in line with intuition: if a settlement is not found by day 20 , then the effect of a tactical delay (suspension) on phase II is not significant because remedies

\footnotetext{
${ }^{21}$ The full table of estimates is included in the Appendix.

${ }^{22}$ The interaction dummy (rem $\times$ suspp 1$)$ is dropped from all models as rem $\times \operatorname{suspp} 1=1$ always results in a phase I finish.
} 
can still be offered after day 20 and so - in terms of the probability of phase II - cases that were suspended are not significantly different from cases that were not. Suspension has a significant effect if parties fail to make a settlement offer by day 30 or day 35 of the procedure. In these cases - as there is very little time left for subsequent settlement offers, suspension helps in avoiding phase II investigations by allowing more time for the parties to come up with a suitable offer.

The evidence implies that by allowing the suspension of proceedings the EC allows for merging firms to tactically delay the proceedings (by failing to disclose the required information to the Commission) and gain more time for finding and adequate settlement offer. This can save the scarce resources of the Commission and may also reduce the risks of a failed merger caused by phase II induced delay.

As far as the cost of delay is concerned, Table 7 shows that if remedies have not been offered, cost of delay ( $v a l$ ) does not have a significant impact on the probability of suspension. If remedies have been offered then cost of delay reduces the chances of suspension. When a merger has already made a remedy offer then a phase I settlement is more likely, therefore mergers with higher cost of delay are more willing to cooperate to avoid suspension and the resulting delay.

Cost of delay has a negative impact on the probability of phase II when remedies are not offered by day $20,25,30$ or 35 . As a suitable remedy is needed for phase I approval, this suggests that when cost of delay is high, parties are more likely to find a remedy in due time even if they had not made an offer by the analysed dates. The results also show that once a remedy has been offered, cost of delay has no further effect on the probability of phase II. This finding is in line with theoretical works that increasing costs of delay may act as a catalyst for early settlement. ${ }^{23}$ This is also equivalent to the case in Miceli (1999) where, in the absence of a delay, the defendant would have gone to trial, and therefore this type of delay lowers social costs as well as the parties' litigation costs.

\footnotetext{
${ }^{23}$ Fournier and Zuehlke (1996).
} 
For this reason it is possible that the Commission acknowledges the use of the phase I suspension of investigations as long as it leads to a simplified assessment of mergers and consequently to a better use of resources. As Portugal explained in one of its ICLG submissions: "some of the cases suggest that the Authority might be willing to suspend the phase 1 deadline for longer periods in order to close the case without initiating phase 2". ${ }^{24}$

\subsection{Suspension in phase II}

To analyse phase II suspensions, the same set of variables were used with the exception of the cost of delay variable ( $\mathrm{val}$ ) which by theory should not impact the probability of merger prohibition. An important caveat to make before discussing these findings is that given the small number of prohibition cases the results to follow have to be interpreted very carefully. The hypothesis, that the correlation coefficient for the error terms $\rho=0$ was not rejected (see Table 9), therefore the single equation probit models (reported in Table 10) were assumed to provide consistent estimates.

Table 5: Probability of prohibition - single equation probit estimates

\begin{tabular}{cc|c|c|c} 
& rem40 & rem60 & rem80 & rem100 \\
\hline \hline suspp2 & 0.748 & 0.692 & 0.667 & 0.698 \\
& $(0.821)$ & $(0.824)$ & $(0.813)$ & $(0.762)$ \\
rem & $-0.835^{*}$ & $-0.917^{* *}$ & $-1.096^{* *}$ & $-0.908^{*}$ \\
& $(0.483)$ & $(0.463)$ & $(0.473)$ & $(0.541)$
\end{tabular}

Table 5 suggests that remedy-offers reduce the probability of prohibition, however suspension has no effect on prohibition. If a remedy is not offered by the given dates (day 40,60,80, or 100) then suspension does nothing in helping to avoid prohibition. This reflects what one would think intuitively: if 4-5 months was not enough for merging parties to offer sufficient remedies, then it is hard to imagine that the extra time gained by the suspension of the

\footnotetext{
${ }^{24}$ Leitão, Teles, and Da Silva (2009). An inventory of the relevant European member state level legislation is given in the Appendix in Table 7.
} 
investigation would bring the parties much closer to a successful remedy-offer.. This suggests that the suspension of merger investigations in their second phase may not have a purpose as socially beneficial as suspensions in phase I.

\section{Conclusion}

Past literature has not dedicated much attention to delay in litigation caused by the strategic behaviour of the parties. In past works delay is typically perceived as being costly and thus undesirable for the society. Miceli (1999) proposed a distinction between two types of delays and identifies occasions where delay is socially beneficial. This paper provided an empirical example to such strategic delay that parties to litigation can use to gain time to make a settlement offer and avoid an even larger delay.

The example given in the paper is taken from the European Commission's merger litigation practice. Evidence is provided that in cases where mergers are found to be problematic, merging parties (or their legal advisors) may tactically delay the procedure (by causing a suspension) until they find a remedial proposal which is likely to settle the case without the need to engage in a lengthy and costly second phase investigation. Phase II suspensions however on average do not help in avoiding the prohibition and the (typically) subsequent judicial review of the case. In these cases the delay in an already lengthy phase II procedure may be indicative of parties with lower delay costs. Whilst phase I strategic delay serves a socially desirable goal (saving of regulatory resources, and reducing the risks threatening successful merger integration), phase II delay only seem to indicate merging parties negligence about delay and the success of their merger. In these cases policymakers should ask the question: what is the social value of a merger, where a delay is treated so light-handedly by the merging parties? ${ }^{25}$

Using the analogies between administrative and civil proceeding, these re-

\footnotetext{
${ }^{25}$ For the above reasons it seems that a regulation like the one in Portugal or in Italy, which recognises the difference between phase I and phase II suspensions, and only allows indefinite-length suspensions in phase I procedures, may seem more appropriate.
} 
sults can be generalised to apply for other areas of law, especially in cases where the pre-trial phase of litigation is characterised by time constraints.

\section{References}

Choparda, B., T. Cortadeb, and E. Langlais (2010): "Trial and Settlement Negotiations Between Asymmetrically Skilled Parties," International Review of Law and Economics, 30, 18-27.

Dewatripont, M., and J. Tirole (1999): "Advocates," Journal of Political Economy, 107(1), 1-39.

Djankov, S., R. La Porta, F. López de Silanes, and A. Shleifer (2003): "Courts," Quarterly Journal of Economics, 118, 453-517.

Fenn, P., And N. Rickman (1999): "Delay and Settlement in Litigation," The Economic Journal, 109(457), 476-491.

Fournier, G., and T. Zuehlke (1996): "The Timing of Out-of-Court Settlements," Rand Journal of Economics, 27, 310-321.

Fré, A. (2005): "Delaying Tactics in Arbitration," Dispute Resolution Journal, Nov 2004-Jan 2005.

Garrod, L., And B. Lyons (2011): "Early Settlement and Errors in Merger Control," CCP Working Paper, 11-5.

Hazard, G. C. J., And W. W. Hodes (2001): Law of Lawyering. Aspen Publishers, third edn.

Heim, M. (2003): "Problems and Process: European Merger Control and How to Use It," Journal of Public Affairs, 4(1), 73-85.

Kessler, D. (1996): "Institutional Causes of Delay in the Settlement of Legal Disputes," Journal of Law, Economics, and Organization, 12, 432-460. 
Leitão, M., G. Teles, and S. Da Silva (2009): "The International Comparative Legal Guide to: Merger Control 2009 - Portugal," A Global Legal Group Publication.

Miceli, T. J. (1999): "Settlement Delay as a Sorting Device," International Review of Law and Economics, 19, 265-274.

Mnookin, R. H., and R. B. Wilson (1989): "Rational Bargaining and Market Efficiency: Understanding Pennzoil V. Texaco," Virginia Law Review, 75(2), 295-334.

Vita, G. D. (2010): "Production of Laws and Delays in Court Decisions," International Review of Law and Economics, 30, 276-281.

Williams, P. L., and R. A. Williams (1994): "The Cost of Civil Litigation: An Empirical Study," International Review of Law and Economics, 14(1), $73-86$.

\section{APPENDIX}


Table 6: Description of variables

\begin{tabular}{llcc} 
Variable & Description & Obs & Mean \\
\hline phase & 1 if case was referred to phase II & 214 & 0.30 \\
suspp1 & 1 if case was suspended in phase I & 214 & 0.14 \\
suspp2 & 1 if case was suspended in phase II & 214 & 0.05 \\
rem1 & Number of working days between notification and first remedy & 193 & 38.80 \\
rem20 & 1 if first remedy offered by day 20 of procedure & 193 & 0.42 \\
rem25 & 1 if first remedy offered by day 25 of procedure & 193 & 0.62 \\
rem30 & 1 if first remedy offered by day 30 of procedure & 193 & 0.69 \\
rem35 & 1 if first remedy offered by day 35 of procedure & 193 & 0.72 \\
rem40 & 1 if first remedy offered by day 40 of procedure & 193 & 0.74 \\
rem60 & 1 if first remedy offered by day 60 of procedure & 193 & 0.78 \\
rem80 & 1 if first remedy offered by day 80 of procedure & 193 & 0.81 \\
rem100 & 1 if first remedy offered by day 100 of procedure & 193 & 0.91 \\
val & Synergies signalled to shareholders & 198 & 0.11 \\
ovlperc & Proportion of market overlaps with competition concerns & 211 & 0.37 \\
vert & 1 if merger had anti-competitive vertical effects & 214 & 0.20 \\
coor & 1 if merger had anti-competitive coordinated effects & 214 & 0.14 \\
cno & Case number & 214 & 3268.02 \\
pa & Value of merger transaction & 214 & 7893.34
\end{tabular}


Table 7: Probability of phase II - recursive bivariate probit estimates

\begin{tabular}{|c|c|c|c|c|c|c|}
\hline & rem20 & \multicolumn{2}{|c|}{ rem25 } & \multicolumn{2}{|c|}{ rem30 } & rem35 \\
\hline \multicolumn{7}{|l|}{ suspp1 } \\
\hline \multirow[t]{2}{*}{ vald } & 0.339 & 0.505 & & 0.520 & & 0.777 \\
\hline & $(0.708)$ & $(0.702)$ & & $(0.778)$ & & $(0.855)$ \\
\hline \multirow[t]{2}{*}{ cno } & $-0.000^{* *}$ & -0.000 & -0.000 & -0.000 & -0.000 & -0.000 \\
\hline & $(0.000)$ & $(0.000)$ & $(0.000)$ & $(0.000)$ & $(0.000)$ & $(0.000)$ \\
\hline \multirow[t]{2}{*}{$p a$} & -0.000 & -0.000 & & -0.000 & & -0.000 \\
\hline & $(0.000)$ & $(0.000)$ & & $(0.000)$ & & $(0.000)$ \\
\hline \multirow[t]{2}{*}{ rem } & -0.274 & $-0.766^{* * *}$ & $-1.071^{* * *}$ & $-0.922^{* * *}$ & $-1.146^{* * *}$ & $-0.880^{* * *} *$ \\
\hline & $(0.299)$ & $(0.287)$ & $(0.237)$ & (0.303) & $(0.246)$ & $(0.300)$ \\
\hline \multirow[t]{2}{*}{ rem $\times$ val } & $-4.658^{* *}$ & $-4.270^{* *}$ & & $-4.673^{* *}$ & & $-5.384^{* *}$ \\
\hline & $(2.056)$ & (1.897) & & $(2.049)$ & & $(2.338)$ \\
\hline \multirow[t]{2}{*}{ cons } & -0.014 & -0.053 & -0.282 & -0.001 & -0.175 & -0.003 \\
\hline & $(0.409)$ & $(0.417)$ & $(0.346)$ & $(0.443)$ & $(0.361)$ & $(0.463)$ \\
\hline \multicolumn{7}{|l|}{ phase } \\
\hline \multirow[t]{2}{*}{ rem } & $-1.233^{* * *}$ & $-1.951^{* * *}$ & $-2.065 * * *$ & $-2.670 * * *$ & $-2.823^{* * *}$ & $-3.495^{* * *}$ \\
\hline & $(0.294)$ & $(0.276)$ & $(0.324)$ & $(0.328)$ & $(0.296)$ & $(0.519)$ \\
\hline \multirow[t]{2}{*}{ suspp 1} & -0.552 & $-1.424^{* *}$ & -1.061 & $-1.892^{* * *}$ & $-2.043^{*}$ & $-2.641^{* * *}$ \\
\hline & $(0.809)$ & $(0.641)$ & $(1.020)$ & $(0.679)$ & $(1.095)$ & $(0.810)$ \\
\hline \multirow[t]{2}{*}{ rem $\times$ susp } & $-4.233^{* * *}$ & $-4.040 * * *$ & & $-4.438 * * *$ & & $-3.598 * * *$ \\
\hline & $(0.594)$ & $(0.630)$ & & $(0.634)$ & & $(0.825)$ \\
\hline \multirow[t]{2}{*}{ ovlperc } & $2.027^{* * *}$ & $2.056^{* * *}$ & $1.893^{* * *}$ & $2.403^{* * *}$ & $1.991^{* * *}$ & $2.216^{* * *}$ \\
\hline & $(0.591)$ & $(0.633)$ & $(0.428)$ & $(0.698)$ & $(0.524)$ & $(0.738)$ \\
\hline \multirow[t]{2}{*}{ vert } & 0.517 & 0.627 & & 0.604 & & 0.191 \\
\hline & $(0.494)$ & $(0.505)$ & & $(0.538)$ & & $(0.626)$ \\
\hline \multirow[t]{2}{*}{ coor } & 0.328 & 0.084 & & 0.368 & & 0.627 \\
\hline & $(0.604)$ & $(0.649)$ & & $(0.767)$ & & $(0.657)$ \\
\hline \multirow[t]{2}{*}{ ovlp $\times$ coor } & -0.038 & 0.234 & & -0.334 & & -0.822 \\
\hline & $(1.077)$ & (1.130) & & $(1.319)$ & & $(1.225)$ \\
\hline \multirow[t]{2}{*}{ ovlp $\times$ vert } & -0.403 & -0.886 & & -1.078 & & -0.616 \\
\hline & $(0.921)$ & $(0.993)$ & & $(1.073)$ & & $(1.215)$ \\
\hline \multirow[t]{2}{*}{ cno } & $-0.000^{* *}$ & -0.000 & & -0.000 & & -0.000 \\
\hline & $(0.000)$ & $(0.000)$ & & $(0.000)$ & & $(0.000)$ \\
\hline \multirow[t]{2}{*}{$p a$} & 0.000 & 0.000 & & 0.000 & & \\
\hline & $(0.000)$ & $(0.000)$ & & $(0.000)$ & & \\
\hline \multirow[t]{2}{*}{ cons } & -0.334 & -0.025 & -0.121 & 0.528 & 0.652 & $1.285^{*}$ \\
\hline & $(0.563)$ & $(0.540)$ & $(0.354)$ & $(0.598)$ & $(0.421)$ & $(0.711)$ \\
\hline $\mathrm{N}$ & 177 & 177 & 190 & 177 & 190 & 177 \\
\hline log-likelihood & -134.870 & -116.251 & -127.675 & -101.873 & -112.192 & -94.220 \\
\hline Wald test of $\rho=0$ & 0.062 & 0.922 & 0.026 & 0.544 & 0.212 & 0.523 \\
\hline$p$-value & 0.803 & 0.337 & 0.871 & 0.461 & 0.645 & 0.470 \\
\hline
\end{tabular}


Table 8: Probability of phase II - single equation probit estimates

\begin{tabular}{|c|c|c|c|c|c|c|}
\hline & rem20 & \multicolumn{2}{|c|}{ rem25 } & \multicolumn{2}{|c|}{ rem30 } & rem35 \\
\hline suspp1 & $\begin{array}{l}-0.369 \\
(0.446)\end{array}$ & $\begin{array}{c}-0.856^{*} \\
(0.460)\end{array}$ & $\begin{array}{c}-0.892^{* *} \\
(0.392)\end{array}$ & $\begin{array}{c}-1.523^{* * *} \\
(0.476)\end{array}$ & $\begin{array}{c}-1.481^{* * *} \\
(0.429)\end{array}$ & $\begin{array}{c}-2.696^{* * *} \\
(0.440)\end{array}$ \\
\hline rem & $\begin{array}{c}-1.367^{* * * *} \\
(0.318)\end{array}$ & $\begin{array}{c}-2.047^{* * *} \\
(0.314)\end{array}$ & $\begin{array}{c}-2.025^{* * *} \\
(0.263)\end{array}$ & $\begin{array}{c}-2.777^{* * *} \\
(0.352)\end{array}$ & $\begin{array}{c}-2.730^{* * *} \\
(0.307)\end{array}$ & $\begin{array}{c}-4.271^{* * *} \\
(0.400)\end{array}$ \\
\hline rem $\times$ susp & (dropped) & (dropped) & (dropped) & (dropped) & (dropped) & (dropped) \\
\hline val & $\begin{array}{c}\cdot \\
-2.039^{*} \\
(1.074)\end{array}$ & $\begin{array}{l}-2.016 \\
(1.271)\end{array}$ & & $\begin{array}{c}-1.729 * * \\
(0.843)\end{array}$ & & $\begin{array}{c}-2.169^{* * *} \\
(0.717)\end{array}$ \\
\hline $\mathrm{rem} \times \mathrm{val}$ & $\begin{array}{c}1.883 \\
(1.210)\end{array}$ & $\begin{array}{c}1.845 \\
(1.331)\end{array}$ & & $\begin{array}{c}1.427 \\
(0.959)\end{array}$ & & $\begin{array}{l}1.985^{* *} \\
(0.836)\end{array}$ \\
\hline ovlperc & $\begin{array}{c}1.952^{* * *} \\
(0.595)\end{array}$ & $\begin{array}{c}2.016^{* * *} \\
(0.630)\end{array}$ & $\begin{array}{c}1.895^{* * *} \\
(0.428)\end{array}$ & $\begin{array}{c}2.303^{* * *} \\
(0.694)\end{array}$ & $\begin{array}{c}2.032^{* * * *} \\
(0.466)\end{array}$ & $\begin{array}{c}2.112^{* * *} \\
(0.737)\end{array}$ \\
\hline vert & $\begin{array}{c}0.337 \\
(0.509)\end{array}$ & $\begin{array}{c}0.486 \\
(0.516)\end{array}$ & & $\begin{array}{c}0.458 \\
(0.542)\end{array}$ & & $\begin{array}{l}-0.110 \\
(0.722)\end{array}$ \\
\hline coor & $\begin{array}{c}0.225 \\
(0.652)\end{array}$ & $\begin{array}{l}-0.025 \\
(0.722)\end{array}$ & & $\begin{array}{c}0.275 \\
(0.816)\end{array}$ & & $\begin{array}{c}0.502 \\
(0.738)\end{array}$ \\
\hline ovlp $\times$ vert & $\begin{array}{l}-0.124 \\
(0.939)\end{array}$ & $\begin{array}{l}-0.588 \\
(0.998)\end{array}$ & & $\begin{array}{l}-0.874 \\
(1.086)\end{array}$ & & $\begin{array}{l}-0.253 \\
(1.338)\end{array}$ \\
\hline ovlp $\times$ coor & $\begin{array}{c}0.235 \\
(1.192)\end{array}$ & $\begin{array}{c}0.575 \\
(1.295)\end{array}$ & & $\begin{array}{c}0.000 \\
(1.432)\end{array}$ & & $\begin{array}{l}-0.421 \\
(1.340)\end{array}$ \\
\hline cno & $\begin{array}{c}-0.000^{* *} \\
(0.000)\end{array}$ & $\begin{array}{l}-0.000 \\
(0.000)\end{array}$ & & $\begin{array}{l}-0.000 \\
(0.000)\end{array}$ & & $\begin{array}{c}0.000 \\
(0.000)\end{array}$ \\
\hline$p a$ & $\begin{array}{c}0.000 \\
(0.000)\end{array}$ & $\begin{array}{l}0.000^{*} \\
(0.000)\end{array}$ & & $\begin{array}{c}0.000 \\
(0.000)\end{array}$ & & $\begin{array}{c}0.000 \\
(0.000)\end{array}$ \\
\hline cons & $\begin{array}{l}-0.238 \\
(0.489)\end{array}$ & $\begin{array}{l}-0.165 \\
(0.511)\end{array}$ & $\begin{array}{l}-0.165 \\
(0.240)\end{array}$ & $\begin{array}{c}0.591 \\
(0.606)\end{array}$ & $\begin{array}{c}0.494 \\
(0.308)\end{array}$ & $\begin{array}{c}2.005^{* * *} \\
(0.610)\end{array}$ \\
\hline $\mathrm{N}$ & 173 & 173 & 186 & 172 & 185 & 171 \\
\hline log-likelihood & -75.706 & -62.078 & -69.003 & -50.103 & -54.948 & -41.825 \\
\hline $\begin{array}{l}\text { Pseudo R2 } \\
* * * \text { significant } \\
\text { standard errol }\end{array}$ & $\begin{array}{l}0.284 \\
0.01, * *\end{array}$ & $\begin{array}{l}0.413 \\
\text { iificant }\end{array}$ & $\begin{array}{c}0.394 \\
05, * \text { sig }\end{array}$ & $\begin{array}{l}0.525 \\
\text { ant at } 0.1\end{array}$ & 0.516 & 0.602 \\
\hline
\end{tabular}


Table 9: Probability of prohibition - recursive bivariate probit estimates

\begin{tabular}{|c|c|c|c|c|c|c|}
\hline suspp2 & rem40 & \multicolumn{2}{|c|}{ rem60 } & \multicolumn{2}{|c|}{ rem80 } & rem90 \\
\hline & & & & & & \\
\hline val & $\begin{array}{l}-1.442 \\
(3.250)\end{array}$ & $\begin{array}{l}-0.531 \\
(3.688)\end{array}$ & & $\begin{array}{l}-3.859 \\
(2.945)\end{array}$ & & $\begin{array}{l}-0.624 \\
(3.993)\end{array}$ \\
\hline rem & $\begin{array}{c}-1.621^{* * *} \\
(0.452)\end{array}$ & $\begin{array}{c}-1.770^{* * *} \\
(0.446)\end{array}$ & $\begin{array}{c}-1.232^{* * *} \\
(0.395)\end{array}$ & $\begin{array}{c}-1.320^{* * *} \\
(0.444)\end{array}$ & $\begin{array}{c}-0.893^{* *} \\
(0.375)\end{array}$ & $\begin{array}{c}-0.923^{*} \\
(0.471)\end{array}$ \\
\hline $\mathrm{rem} \times \mathrm{val}$ & $\begin{array}{c}2.170 \\
(3.318)\end{array}$ & $\begin{array}{c}1.260 \\
(3.714)\end{array}$ & & $\begin{array}{c}4.310 \\
(3.010)\end{array}$ & & $\begin{array}{c}0.672 \\
(1.829)\end{array}$ \\
\hline cno & $\begin{array}{c}0.000^{* * *} \\
(0.000)\end{array}$ & $\begin{array}{c}0.000^{* * *} \\
(0.000)\end{array}$ & $\begin{array}{c}0.000^{* *} \\
(0.000)\end{array}$ & $\begin{array}{c}0.000^{* *} \\
(0.000)\end{array}$ & $\begin{array}{c}0.000^{* *} \\
(0.000)\end{array}$ & $\begin{array}{c}0.000^{* * *} \\
(0.000)\end{array}$ \\
\hline$p a$ & $\begin{array}{l}-0.000 \\
(0.000)\end{array}$ & $\begin{array}{l}-0.000 \\
(0.000)\end{array}$ & & $\begin{array}{l}-0.000 \\
(0.000)\end{array}$ & & $\begin{array}{l}-0.000 \\
(0.000)\end{array}$ \\
\hline cons & $\begin{array}{c}-2.427^{* * *} \\
(0.435)\end{array}$ & $\begin{array}{c}-2.339^{* * *} \\
(0.474)\end{array}$ & $\begin{array}{c}-2.075^{* * *} \\
(0.451)\end{array}$ & $\begin{array}{c}-1.972^{* * *} \\
(0.492)\end{array}$ & $\begin{array}{c}-1.955^{* * *} \\
(0.417)\end{array}$ & $\begin{array}{c}-1.660^{* * *} \\
(0.546)\end{array}$ \\
\hline prohib & & & & & & \\
\hline rem & $\begin{array}{c}-1.195^{* *} \\
(0.549)\end{array}$ & $\begin{array}{c}-1.262^{* * *} \\
(0.475)\end{array}$ & $\begin{array}{c}-1.396^{* * *} \\
(0.401)\end{array}$ & $\begin{array}{c}-1.288^{* * *} \\
(0.316)\end{array}$ & $\begin{array}{c}-1.294^{* * *} \\
(0.397)\end{array}$ & $\begin{array}{c}-0.765^{* * *} \\
(0.547)\end{array}$ \\
\hline suspp2 & $\begin{array}{l}-0.982 \\
(0.732)\end{array}$ & $\begin{array}{l}-1.001 \\
(0.633)\end{array}$ & $\begin{array}{c}-1.045^{* * *} \\
(0.403)\end{array}$ & $\begin{array}{c}-1.118^{* *} \\
(0.475)\end{array}$ & $\begin{array}{c}-1.029^{* *} \\
(0.403)\end{array}$ & $\begin{array}{l}-1.718 \\
(2.153)\end{array}$ \\
\hline ovlperc & $\begin{array}{c}0.859 \\
(1.115)\end{array}$ & $\begin{array}{c}0.859 \\
(1.056)\end{array}$ & $\begin{array}{c}1.098^{*} \\
(0.560)\end{array}$ & $\begin{array}{c}0.753 \\
(0.654)\end{array}$ & $\begin{array}{l}1.036^{*} \\
(0.605)\end{array}$ & $\begin{array}{l}1.324 \\
(1.285)\end{array}$ \\
\hline coor & $\begin{array}{l}-1.859 \\
(1.419)\end{array}$ & $\begin{array}{l}-2.060 \\
(3.803)\end{array}$ & & $\begin{array}{c}-1.569^{* *} \\
(0.753)\end{array}$ & & $\begin{array}{l}-1.398 \\
(0.981)\end{array}$ \\
\hline vert & $\begin{array}{c}0.058 \\
(1.210)\end{array}$ & $\begin{array}{c}0.288 \\
(1.099)\end{array}$ & & $\begin{array}{c}0.334 \\
(0.687)\end{array}$ & & $\begin{array}{c}0.714 \\
(2.489)\end{array}$ \\
\hline ovlp $\times$ coor & $\begin{array}{c}2.261 \\
(1.996)\end{array}$ & $\begin{array}{c}2.495 \\
(4.183)\end{array}$ & & $\begin{array}{l}1.935^{*} \\
(1.054)\end{array}$ & & $\begin{array}{c}3.190 \\
(3.070)\end{array}$ \\
\hline ovlp $\times$ vert & $\begin{array}{c}0.653 \\
(1.671)\end{array}$ & $\begin{array}{c}0.447 \\
(1.484)\end{array}$ & & $\begin{array}{c}0.229 \\
(1.143)\end{array}$ & & $\begin{array}{c}0.149 \\
(1.753)\end{array}$ \\
\hline cno & $\begin{array}{c}0.000 \\
(0.000)\end{array}$ & $\begin{array}{c}0.000 \\
(0.000)\end{array}$ & & $\begin{array}{c}0.000 \\
(0.000)\end{array}$ & & $\begin{array}{l}-0.000 \\
(0.000)\end{array}$ \\
\hline$p a$ & $\begin{array}{l}-0.000 \\
(0.000)\end{array}$ & $\begin{array}{l}-0.000 \\
(0.000)\end{array}$ & & $\begin{array}{l}-0.000 \\
(0.000)\end{array}$ & & $\begin{array}{l}-0.000 \\
(0.000)\end{array}$ \\
\hline cons & $\begin{array}{l}-1.633 \\
(1.074)\end{array}$ & $\begin{array}{c}-1.509^{* *} \\
(0.725)\end{array}$ & $\begin{array}{c}-1.402^{* * *} \\
(0.412)\end{array}$ & $\begin{array}{c}-1.312^{* *} \\
(0.625)\end{array}$ & $\begin{array}{c}-1.339^{* * *} \\
(0.460)\end{array}$ & $\begin{array}{l}-1.414 \\
(1.912)\end{array}$ \\
\hline $\mathrm{N}$ & 177 & 177 & 190 & 177 & 190 & 177 \\
\hline log-likelihood & -46.393 & -44.873 & -49.112 & -48.035 & -51.609 & -53.296 \\
\hline Wald test of $\rho=0$ & 0.370 & 0.025 & 0.003 & 0.039 & 0.081 & 0.374 \\
\hline$p$-value & 0.543 & 0.874 & 0.956 & 0.844 & 0.776 & 0.541 \\
\hline
\end{tabular}

$* * *$ significant at $0.01, * *$ significant at $0.05, *$ significant at 0.1

standard errors between brackets 
Table 10: Probability of prohibition - single equation probit estimates

\begin{tabular}{|c|c|c|c|c|c|c|}
\hline \multirow[b]{2}{*}{ suspp2 } & \multirow{2}{*}{$\begin{array}{c}\text { rem40 } \\
0.748 \\
(0.821)\end{array}$} & \multicolumn{2}{|c|}{ rem60 } & \multicolumn{2}{|c|}{ rem80 } & \multirow{2}{*}{$\begin{array}{c}\text { rem100 } \\
0.698 \\
(0.762)\end{array}$} \\
\hline & & $\begin{array}{c}0.692 \\
(0.824)\end{array}$ & $\begin{array}{c}0.502 \\
(0.624)\end{array}$ & $\begin{array}{c}0.667 \\
(0.813)\end{array}$ & $\begin{array}{c}0.598 \\
(0.618)\end{array}$ & \\
\hline rem & $\begin{array}{c}-0.835^{*} \\
(0.483)\end{array}$ & $\begin{array}{c}-0.917^{* *} \\
(0.463)\end{array}$ & $\begin{array}{c}-1.156^{* *} \\
(0.462)\end{array}$ & $\begin{array}{c}-1.096^{* *} \\
(0.473)\end{array}$ & $\begin{array}{c}-1.280^{* * *} \\
(0.468)\end{array}$ & $\begin{array}{c}-0.908^{*} \\
(0.541)\end{array}$ \\
\hline ovlperc & $\begin{array}{c}1.575 \\
(1.024)\end{array}$ & $\begin{array}{c}1.518 \\
(1.101)\end{array}$ & $\begin{array}{c}1.872^{* * *} \\
(0.691)\end{array}$ & $\begin{array}{c}1.486 \\
(1.116)\end{array}$ & $\begin{array}{c}1.834^{* * *} \\
(0.694)\end{array}$ & $\begin{array}{c}1.282 \\
(1.193)\end{array}$ \\
\hline vert & $\begin{array}{c}0.255 \\
(1.198)\end{array}$ & $\begin{array}{c}0.439 \\
(1.180)\end{array}$ & & $\begin{array}{c}0.627 \\
(1.110)\end{array}$ & & $\begin{array}{c}0.698 \\
(0.970)\end{array}$ \\
\hline coor & $\begin{array}{l}-3.185 \\
(3.127)\end{array}$ & $\begin{array}{l}-3.047 \\
(3.826)\end{array}$ & & $\begin{array}{l}-3.030 \\
(3.368)\end{array}$ & & $\begin{array}{l}-2.590 \\
(2.369)\end{array}$ \\
\hline ovlp $\times$ vert & $\begin{array}{c}0.354 \\
(1.729)\end{array}$ & $\begin{array}{c}0.158 \\
(1.728)\end{array}$ & & $\begin{array}{l}-0.079 \\
(1.632)\end{array}$ & & $\begin{array}{c}0.300 \\
(1.552)\end{array}$ \\
\hline ovlp $\times$ coor & $\begin{array}{c}3.674 \\
(3.660)\end{array}$ & $\begin{array}{c}3.533 \\
(4.308)\end{array}$ & & $\begin{array}{c}3.444 \\
(3.868)\end{array}$ & & $\begin{array}{c}3.054 \\
(2.944)\end{array}$ \\
\hline cno & $\begin{array}{l}-0.000 \\
(0.000)\end{array}$ & $\begin{array}{l}-0.000 \\
(0.000)\end{array}$ & & $\begin{array}{l}-0.000 \\
(0.000)\end{array}$ & & $\begin{array}{c}-0.000^{*} \\
(0.000)\end{array}$ \\
\hline$p a$ & $\begin{array}{l}-0.000 \\
(0.000)\end{array}$ & $\begin{array}{l}-0.000 \\
(0.000)\end{array}$ & & $\begin{array}{l}-0.000 \\
(0.000)\end{array}$ & & $\begin{array}{l}-0.000 \\
(0.000)\end{array}$ \\
\hline cons & $\begin{array}{l}-1.776^{*} \\
(0.909)\end{array}$ & $\begin{array}{c}-1.594^{*} \\
(0.949)\end{array}$ & $\begin{array}{c}-2.392^{* * *} \\
(0.536)\end{array}$ & $\begin{array}{l}-1.479 \\
(0.956)\end{array}$ & $\begin{array}{c}-2.282^{* * *} \\
(0.540)\end{array}$ & $\begin{array}{l}-1.290 \\
(0.982)\end{array}$ \\
\hline $\mathrm{N}$ & 190 & 190 & 190 & 190 & 190 & 190 \\
\hline log-likelihood & -17.478 & -17.081 & -18.361 & -16.347 & -17.599 & -17.314 \\
\hline Pseudo R2 & 0.344 & 0.359 & 0.311 & 0.386 & 0.339 & 0.350 \\
\hline
\end{tabular}


Table 11: A European comparison of the suspension of merger procedures

\begin{tabular}{|c|c|c|}
\hline Country & $\begin{array}{l}\text { Reference in } \\
\text { Competition Act }\end{array}$ & Comment \\
\hline \multicolumn{3}{|c|}{ With indefinite length of suspension: } \\
\hline Belgium & Article $44(2)$ & \\
\hline Czech Republic & Article $16(6)$ & \\
\hline Estonia & Article 27 (10) & \\
\hline European Commission & Article $10(4)$ & \\
\hline France & LME Act & \\
\hline Germany & Article 40 (2) 1) & Needs parties' agreement \\
\hline Italy & Article 16(7) & Only for phase I \\
\hline Netherlands & Article $38(2)$ & \\
\hline Norway & Section 20 & \\
\hline Poland & Article 96 (3) & \\
\hline \multirow[t]{2}{*}{ Portugal } & Article 34 (3) & \\
\hline & Article 36 (2) & \\
\hline Romania & Article 51 (4) & \\
\hline Slovakia & Article 11 & \\
\hline Slovenia & Article $47(2)$ & \\
\hline \multirow[t]{2}{*}{ United Kingdom } & Section $25(2)-(3)$ & \\
\hline & Enterprise Act & \\
\hline \multicolumn{3}{|c|}{ With definite-length suspension } \\
\hline Denmark & Article 12d (3) & \\
\hline Hungary & Article $63(6)$ & $\begin{array}{l}60 \text { days in phase II } \\
\text { and by } 20 \text { days in phase I }\end{array}$ \\
\hline Iceland & Article $17 \mathrm{~d}$ & $\begin{array}{l}20 \text { days to obtain } \\
\text { further information }\end{array}$ \\
\hline Ireland & $\begin{array}{l}\text { Article } 20(2), \\
\text { Article } 21(4)\end{array}$ & $\begin{array}{l}\text { Only in phase } \mathrm{I} \text {, which is } \\
\text { extended from } 1 \text { month to } 45 \text { days }\end{array}$ \\
\hline Italy & Article 16 (8) & $\begin{array}{l}\text { Definite for phase II ( } 30 \text { days) } \\
\text { but indefinite for phase I }\end{array}$ \\
\hline Lithuania & Article 13 (4) & 1 month \\
\hline
\end{tabular}

